\title{
Nutrient efficiency and resorption in Quercus pyrenaica oak coppices under different rainfall regimes of the Sierra de Gata mountains (central western Spain)
}

\author{
Juan F. Gallardo ${ }^{\mathrm{a} *}$, Alejandro Martín ${ }^{\mathrm{b}}$, Gerardo Moreno ${ }^{\mathrm{a}}$ \\ a C.S.I.C., Aptdo 257, Salamanca 37071, Spain \\ b Area de Edafología, Facultad of Farmacia, Salamanca 37080, Spain
}

(Received 8 December 1997; accepted 8 January 1999)

\begin{abstract}
Nutrient uptake, nutrient resorption and nutrient use efficiency (NUE) were estimated in four Quercus pyrenaica oak coppices situated in the Sierra de Gata mountains (province of Salamanca, central-western Spain). The efficiency (NUE) with which a given nutrient is used depends on several factors. In the oak coppices studied, availability of $\mathrm{P}, \mathrm{Ca}$ and $\mathrm{Mg}$ in the soil was one of the factors governing efficiency. On the other hand, there was a certain independence between soil $\mathrm{N}$ and $\mathrm{K}$ availability and their plant efficiency; in the case of $\mathrm{N}$ this occurred possibly because it is a limiting factor. There was a plant nutritional $\mathrm{Ca}-\mathrm{Mg}$ imbalance due to soil acidity. Leaf absorption and/or leaching at canopy level would also influence the $\mathrm{N}$ and $\mathrm{K}$ efficiency. The stand with the most dystrophic soil was the least efficient regarding $\mathrm{Mg}$, and the plot with the most eutrophic soil regarding $\mathrm{Ca}$. All the oak coppices had low $\mathrm{N}$ efficiency. Bioelement resorption did not affect the NUE decisively but it seemed to be influenced by leaf absorption and leaching occurring at the canopy level. Higher aboveground production suggested that the stands on granite absorbed greater yearly amounts of N, K and P than those on schist. (@ Inra/Elsevier, Paris.)
\end{abstract}

nutrient use efficiency / resorption / root uptake / oak coppice / Quercus pyrenaica / biogeochemical cycles

Résumé - Efficience et réabsorption d'éléments nutritifs dans quatre taillis à Quercus pyrenaica suivant un transect pluviométrique dans la Sierra de Gata (ouest de l'Espagne). L'absorption d'éléments nutritifs, la réabsorption et l'efficience d'utilisation d'éléments nutritifs (NUE) ont été étudiés dans quatre chênaies (Quercus pyrenaica) de la Sierra de Gata (province de Salamanque, ouest de l'Espagne). L'efficience d'utilisation de bioéléments (NUE) est dépendante de différents facteurs. Dans les chênaies étudiées la disponibilité édaphique des éléments nutritifs influe sur l'efficience d'utilisation de $\mathrm{P}, \mathrm{Ca}$ et $\mathrm{Mg}$. Au contraire, il n'y a pas de relation entre l'efficience de $\mathrm{N}$ et $\mathrm{K}$, et la disponibilité édaphique de ces éléments, peut être en raison des réserves édaphiques importantes de $\mathrm{N}$ total et de l'acidité du sol qui entraîne une insuffisance pour Ca. L'absorption et le lessivage des feuilles des arbres peuvent aussi influencer l'efficience de $\mathrm{N}$ et $\mathrm{K}$. La station avec le sol le plus dystrophe correspond à la chênaie la moins efficiente pour $\mathrm{Mg}$, tandis que la station la moins dystrophe est la chênaie la moins efficiente pour le $\mathrm{Ca}$. En ce qui concerne $\mathrm{N}$, toutes les chênaies ont une efficience très basse. La réabsorption d'éléments biogènes n'affecte pas la NUE des taillis étudiés, parce qu'elle est influencée par les processus d'absorption et le lessivage des bioéléments au niveau de la canopée forestière. Les peuplements sur granit absorbent plus d'N, K et $\mathrm{P}$ et produisent plus de litière que les peuplements sur schistes. ( $\odot$ Inra/Elsevier, Paris.)

efficience d'utilisation des bioéléments / réabsorption / absorption des racines / taillis de chêne / Quercus pyrenaica / cycles de bioéléments

* Correspondence and reprints

jgallard@gugu.usal.es 


\section{Introduction}

Nutrient use efficiency (NUE) has been defined by Ferrés et al. [17] as the biomass production by plants (in terms of fixed C) per unit of nutrient uptake.

NUE appears mostly in the literature with reference to infertile habitats, such as marshes [12], peatlands [7], heathlands [2] or semi-deserts [33]. The efficiency of nutrient use by plants to produce biomass may be an important adaptation to infertile habitats [7]; an increase in NUE in a plant species should be a response to the decreasing soil nutrient availability, but this is not found in general [1]. Furthermore, it is not clear whether the greater NUE observed in oligotrophic soils is a characteristic of the species inhabiting them or whether it is a phenotypical response of individual specimens to low nutrient availability [4].

In short-lived plants, biomass production per unit of absorbed nutrient is simply the inverse of the concentration of the nutrient in question in the tissues of the plant. However, in long-lived plants some bioelements suffer resorption (i.e. reabsorption by young tissues of nutrients retranslocated from senescent tissues as mature leaves), which allows the plants to use the same unit of absorbed nutrient to produce several vegetative organs [38], increasing the NUE. Resorption is the repeated use of the same nutrient units and could therefore be a good means of estimating the efficiency of nutrient use; nevertheless resorption has not been found for all the bioelements, but is frequent for $\mathrm{N}$ and $\mathrm{P}$. Apart from the probable adaptive value of efficient resorption, important interspecies differences in resorption indices have been observed.

Therefore nutrient concentrations only afford a very approximate idea of the efficiency of nutrient use by forest species. In these cases, it seems more appropriate to estimate efficiency by measuring net primary production (aerial and underground) per unit of nutrient uptake during the year. Under controlled conditions, such measurements are possible; however, they are not very practical under field conditions [4].

As an alternative, Vitousek [38] defined NUE (see equation later) as the total amount of organic matter return (as litterfall and root return) plus that stored permanently in the plant (in the wood), divided by the amount of nutrients lost (as litterfall, canopy leaching or by root return) plus the nutrients remaining stored owing to the growth of the vegetation (uptake according to Cole and Rapp [10].

An easier method of calculating the NUE (specifically for forests) was proposed by Vitousek $[38,39]$ as the inverse of the concentration of the nutrient (that is, amount of dry matter in litterfall per unit of the nutrient contained in it). Later, Bridgham et al. [7] used the ratio of 'litterfall production/litterfall nutrient' as an index of nutrient efficiency (NUE; production per unit of resource uptake), distinguishing it from the resource response efficiency (RRE), defined as the production per unit of available resource. In forests an additional problem is the exact measurement of the availability of the resource $[24,25]$.

Carceller et al. [8] reported that under nutrient stress conditions (either due to soil oligotrophy and/or to low water availability, giving rise to deficiency symptoms) some plants respond with increased efficiency. Nevertheless, parameters of both total and available soil nutrients are sometimes not correlated to plant nutrient uptake (in both fertile and very unfertile soils), probably because many factors affect nutrient efficiency in the field.

Vitousek [38] has pointed out that the literature contains many references to litterfall and to the amounts of $\mathrm{N}, \mathrm{P}, \mathrm{Ca}, \mathrm{Mg}$ and $\mathrm{K}$ returned through litterfall, but little information concerning the amount of nutrients stored in wood $[14,31]$ and even less about root return $[8,30]$. Furthermore, Cole and Rapp [10] and Gallardo et al. [20] have shown that $\mathrm{N}-, \mathrm{P}$ - and Ca-return to the soil is mostly achieved through litterfall, while K-return is mainly due to canopy leaching; $\mathrm{Mg}$ is intermediate between these two possibilities and varies according to the ecosystem studied. Consequently, it is difficult to compare the results on NUE from different studies because the data are obtained from different calculations, depending on previous definitions of NUE and the ecosystems. Blair [5] affirmed that the definition of NUE depends on the ecosystem in question (annual, deciduous, evergreen plants, etc.).

Aerts [3] stated that efficiency is also related to nutrient resorption by plants; reviewing the literature he found that nutrient resorption is close to $50 \%$ for $\mathrm{N}$ and $\mathrm{P}$ in some tree species. Del Arco et al. [11] reported that $\mathrm{N}$ resorption is a key process through which plants reach maximum efficiency in their use of $\mathrm{N}$.

Among the factors assumed to exert some effect on the above-mentioned differences in resorption [16] are soil fertility, soil dryness and those affecting leaf demography (leaf shedding period, time of residence of nutrient in leaves). When requirements are greater than uptake, the plant must meet the rest of its needs for nutrients by retranslocating them from old organs to new ones. Following this line of thought, Carceller et al. [8] calculated bioelement resorption as the difference between the leaf mineral mass at the end of August minus the potential return of nutrients to the soil through the leaf litter [20]. 
Significant relationships between leaf nutrient concentration and soil nutrient availability are reported frequently, but Aerts [3] did not find any link between leaf nutrient resorption and leaf nutrient concentration, or soil nutrient availability and leaf nutrient resorption.

Regarding the effect of soil fertility on NUE, several theories have been advanced; it seems logical that species found on the sites most impoverished in soil $\mathrm{P}$ or $\mathrm{N}$ would have higher resorption indices because they would be obliged to retain these elements and reuse them as much as possible, thus favouring more efficient internal recycling [34] and affording the plants a certain independence from the supply coming from the soil. Paradoxically, species living in highly fertile areas may have very high nutritional requirements, leading them to use nutrients more efficiently too [36].

However, in general, the majority of autochthonous European forests are restricted to areas with poor soils. For example, Gallardo et al. [18] have carried out research on deciduous oak (Quercus pyrenaica Willd.) coppices developed on acid soils with low base and available $P$ contents [37]. Other aspects related with the biogeochemical cycles of these forests $[23,26,27,37]$ and their water balance $[28,29]$ have also been studied.

It could thus be of interest to know the NUE and resorption values in four well-studied, oak-forest ecosystems of the Sierra de Gata mountains following a rainfall gradient [19] and to see whether it is possible to find differences between those values in relation to soil characteristics, especially soil $\mathrm{pH}$ and biochemical properties.

The aim of the present work was first to estimate the NUE (according to Vitousek [38]) and resorption of macronutrients on plots of these deciduous oak $(Q$. pyrenaica) coppices and then to elucidate which factors govern these processes, taking into account the soil availability of each macronutrient.

\section{Materials and methods}

\subsection{Site description and stand characteristics}

The study area is located in the El Rebollar district (Sierra de Gata mountains, province of Salamanca, western Spain). The co-ordinates of the area are $40^{\circ} 19^{\prime} \mathrm{N}$ and $6^{\circ} 43^{\prime} \mathrm{W}$.

Four experimental plots of Quercus pyrenaica Willd. coppices were selected (table $I$ ) with areas ranging from 0.6 to 1 ha. They were named Fuenteguinaldo (FG), Villasrubias (VR), El Payo (EP) and Navasfrías (NF). Stand ages range from 60 to about 80 years (table I). These coppices were thinned for pasturing (cattle).
The climate of the area is classified as warm Mediterranean, characterised by wet winters and hot, dry summers [28], with an average rainfall and temperature (table I) of approximately $1580 \mathrm{~L} \mathrm{~m}^{-2}$ year $^{-1}$ and $10.4{ }^{\circ} \mathrm{C}$ for $\mathrm{NF}$, and $720 \mathrm{~L} \mathrm{~m}^{-2}$ year $^{-1}$ and $12.9^{\circ} \mathrm{C}$ for FG.

The dominant soils are humic Cambisols developed over schist and greywackes at NF and VR, and over Caalkaline granite at EP and FG [26]. The physical, physicochemical, and biochemical properties of the four forest soils are shown in table II; soil samples were taken from the selected modal soil profile at each plot [37].

Tree density (table I) ranges between 1043 trees ha $^{-1}$ at the VR plot and 406 trees ha ${ }^{-1}$ at the EP plot $[22,28]$. The plot with the lowest tree density (EP) has the highest mean trunk diameter $(25 \mathrm{~cm})$, the greatest height $(17 \mathrm{~m})$ and biomass $\left(131 \mathrm{Mg} \mathrm{ha}^{-1}\right)$; the lowest values of these parameters correspond to the VR plot $(11 \mathrm{~cm}, 8.5 \mathrm{~m}$ and $63.8 \mathrm{Mg} \mathrm{ha}^{-1}$, respectively). Aboveground production ranged from 4.1 to $2.6 \mathrm{Mg} \mathrm{ha}^{-1}$ year $^{-1}$ in FG and NF, respectively [20].

Methodological aspects and data of soil analysis, aboveground biomass, litterfall production (from February 1990 to February 1993), foliar analysis, rainfall distribution, throughfall, water concentrations of bioelements, canopy $\mathrm{N}$ absorption, annual potential return of bioelements (total nutrients returned to the soil through the litterfall, assuming complete mineralization), etc., have been given by Gallego et al. [22, 23], Martín et al. [26], Moreno et al. [28, 29] and Gallardo et al. [19, 20]. Owing to methodological difficulties, no data on root biomass and below ground production of oak coppices have been obtained. Annual nutrient immobilisation in wood has also been estimated [18]. Exchangeable cations were determined following the neutral ammonium-acetate method [26]; available $\mathrm{Ca}$ and $\mathrm{K}$ using $1 \mathrm{~N}$ ammonium acetate as extracting solution [37]; and available $\mathrm{P}$ using to the Bray-Kurtz [6] procedure.

Some of the important soil characteristics of the stands are shown in table II.

\subsection{Methods}

Each plot was divided into three parts, and in each of the three subplots the same experiments were performed. As a result, data refer in general to a mean of three replicates. Standard deviations were only calculated where data are directly determined by chemical determinations. 
Table I. Characteristics of the four experimental plots (from Gallego et al. [22] and Moreno et al. [29]).

\begin{tabular}{|c|c|c|c|c|}
\hline Stands & $\begin{array}{l}\text { Fuenteguinaldo } \\
\qquad(F G)\end{array}$ & $\begin{array}{l}\text { Villasrubias } \\
\text { (VR) }\end{array}$ & $\begin{array}{l}\text { El Payo } \\
\text { (EP) }\end{array}$ & $\begin{array}{l}\text { Navasfrias } \\
\text { (NF) }\end{array}$ \\
\hline Altitude ( $\mathrm{m}$ a.s.l.) & 870 & 900 & 940 & 960 \\
\hline Mean annual temperature $\left({ }^{\circ} \mathrm{C}\right)$ & 12.9 & N.d. & 8.1 & 10.4 \\
\hline Geology & Ca-alkaline granite & schist and greywackes & $\mathrm{Ca}$-alkaline granite & schist and greywackes \\
\hline Soil [15] & Humic: Cambisol & Humic Cambisol & Humic Cambisol & Humic Cambisol \\
\hline Density (tree ha-1) & 738 & 1043 & 406 & 820 \\
\hline Mean D.B.H. (cm at $1.3 \mathrm{~m})$ & 16.5 & 11.0 & 25.4 & 15.2 \\
\hline Mean height $(\mathrm{m})$ & 12.0 & 8.5 & 17.0 & 13.0 \\
\hline Total biomass ( $\mathrm{Mg} \mathrm{ha}^{-1}$ ) & 98.0 & 63.8 & 131 & 64.5 \\
\hline L.A.I. $\left(\mathrm{m}^{2} \mathrm{~m}^{-2}\right)$ & 2.6 & 2.0 & 1.9 & 1.8 \\
\hline Basal area $\left(\mathrm{m}^{2} \mathrm{ha}^{-1}\right)$ & 21.2 & 13.5 & 19.9 & 15.6 \\
\hline
\end{tabular}

D.B.H.: Mean diameter at breast height $(1.3 \mathrm{~m})$; L.A.I.: leaf area index. ( \pm standard deviation); N.d.: no data available.

\subsubsection{Estimation of tree uptake (TU)}

An estimation of the annual, soil nutrient uptake by plants was made. The tree nutrient uptake from the soil was calculated according to the following equation (units in $\mathrm{kg} \mathrm{ha}^{-1}$ year $^{-1}$ ):

$$
\mathrm{TU}=\mathrm{LF}+\mathrm{SG}+\mathrm{TF}
$$

where TU is tree uptake of the nutrient considered; LF, litterfall; SG, stem growth; and TF, throughfall (nutrients retained in small branches and bark are difficult to determine).

\subsubsection{Calculation of efficiency indices}

Two efficiency indices, involving different factors, were determined.

The first was defined by Vitousek [38] as dry matter of litterfall per unit of nutrient content in litterfall; this index is frequently used for $\mathrm{N}$ and $\mathrm{P}$ (we also use it for $\mathrm{K}$, for comparative purposes) and is shown in table III as NEI (nutrient efficiency index).

The second index determined, GEI (general efficiency index), contains all the terms given by Vitousek [38] except the contribution from roots (not determined in this study) and can therefore be defined by the following formula:

$$
G E I=\frac{L F+S G}{N R+N I+T F}
$$

where LF is litterfall (referred to as kg dry matter ha ${ }^{-1}$ ); $\mathrm{SG}$, stem growth (referred to as kg dry matter $\mathrm{ha}^{-1}$ ); NR, nutrient returned by litterfall (in $\mathrm{kg} \mathrm{ha}^{-1}$ ); NI, nutrient immobilised by stems (in $\mathrm{kg} \mathrm{ha}^{-1}$ ); and TF, throughfall of the nutrient considered (in kg ha-1).

The amount of nutrients absorbed by the leaves at the canopy level [29] is subtracted since these nutrients are of external origin and are not absorbed directly by the roots.

\subsubsection{Estimation of the resorption index $(\mathrm{Re})$}

Taking into account the theoretical considerations expressed above, and in an attempt to overcome the drawbacks involved in the calculation of resorption, the resorption index $(\mathrm{Re})$ was estimated using the following expression (units in $\mathrm{kg} \mathrm{ha}^{-1}$ ):

$$
\operatorname{Re}(\%)=\frac{M M-(N R+C L)}{M M} \times 100
$$

where MM is leaf mineral mass (sum of the masses of the nutrient considered) calculated by harvesting trees of different diameter classes; NR is nutrient return by leaf litter; and CL is nutrient canopy leaching (sensu stricto). In this estimation only the soil losses brought about by root absorption (without considering the increase in root biomass) and the soil gains through leaf litter and throughfall are considered [19]. Thus, the nutrient leaching has also been taken into account in this resorption index, as proposed by Ferrés et al. [17]. 


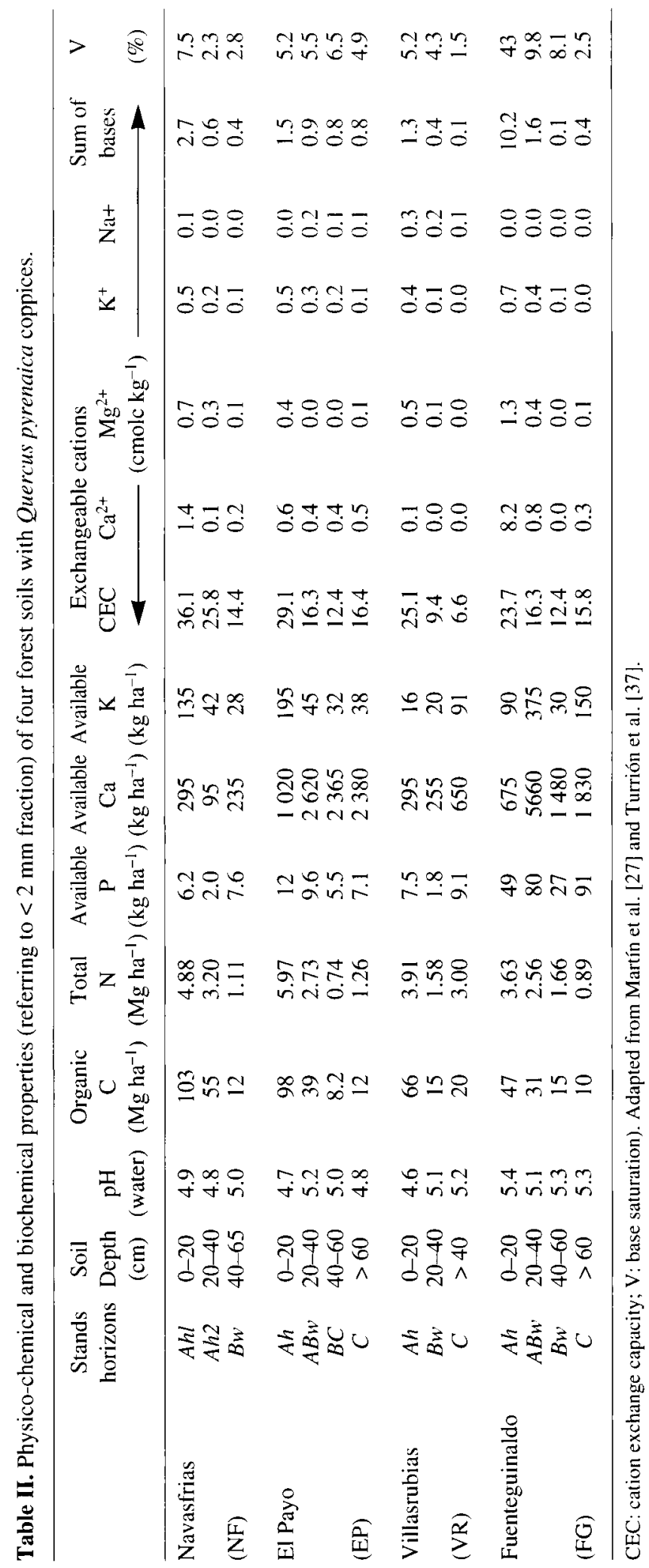


Table III. Mean leaf and litter concentration of bioelements, estimated root uptake of nutrients, and calculated indices of resorption and efficiency (NEI and GEI, respectively).

\begin{tabular}{|c|c|c|c|c|c|c|}
\hline Stands & Bioelements & $\mathrm{N}$ & $\mathrm{P}$ & $\mathrm{Ca}$ & $\mathrm{Mg}$ & $\mathrm{K}$ \\
\hline \multirow[t]{5}{*}{ Navasfr'as } & Mean leaf concentration $\left(\mathrm{mg} \mathrm{g}^{-1}\right)$ & $17.0( \pm 0.8)$ & $1.1( \pm 0.7)$ & $7.0( \pm 0.2)$ & $1.65( \pm 0.06)$ & $3.6( \pm 0.3)$ \\
\hline & Mean litter concentration (mg g ${ }^{-1}$ ) & $14.0( \pm 0.9)$ & $0.6( \pm 0.1)$ & $6.9( \pm 0.3)$ & $2.1( \pm 0.1)$ & $2.2( \pm 0.2)$ \\
\hline & $\begin{array}{l}\text { Root uptake }\left(\mathrm{kg} \mathrm{ha}^{-1} \text { year }^{-1}\right) \\
\text { Resorntion }\end{array}$ & & & & & \\
\hline & $\begin{array}{l}\text { Resorption } \\
\text { Absolute }\left(\mathrm{kg} \mathrm{ha}^{-1} \mathrm{ycar}^{-1}\right)\end{array}$ & 27.0 & 1.8 & & & \\
\hline & $\begin{array}{l}\text { Relative (\%) } \\
\text { Rod yeal }\end{array}$ & 58 & 58 & N.d. & No. & 1.8 \\
\hline \multirow{2}{*}{ (NF) } & NEI & 76 & 1620 & 144 & N.d. & 18 \\
\hline & GEI & 158 & 2124 & 108 & 762 & 362 \\
\hline \multirow[t]{6}{*}{ El Payo } & Mean leaf concentration $\left(\mathrm{mg} \mathrm{g}^{-1}\right)$ & $13.7( \pm 0.2)$ & $1.22( \pm 0.04)$ & $5.1( \pm 0.5)$ & $1.76( \pm 0.06)$ & $7.4( \pm 0.3)$ \\
\hline & Mean litter concentration $\left(\mathrm{mg} \mathrm{g}^{-1}\right)$ & $15.0( \pm 0.8)$ & $0.9( \pm 0.1)$ & $5.7( \pm 0.2)$ & $1.9( \pm 0.1)$ & $2.7( \pm 0.3)$ \\
\hline & Root uptake $\left(\mathrm{kg} \mathrm{ha}^{-1}\right.$ year $\left.{ }^{-1}\right)$ & 52 & 4.2 & 36 & 8.7 & 23 \\
\hline & Resorption & & & & & \\
\hline & Absolute $\left(\mathrm{kg} \mathrm{ha}^{-1}\right.$ year $\left.{ }^{-1}\right)$ & 7.0 & 0.5 & N.d. & N.d. & 3.6 \\
\hline & Relative $(\%)$ & 23 & 18 & N.d. & N.d. & 22 \\
\hline \multirow[t]{2}{*}{ (EP) } & NEI & 71 & 1168 & 176 & N.d. & 370 \\
\hline & GEI & 106 & 1304 & 154 & 626 & 234 \\
\hline \multirow[t]{6}{*}{ Villasrubias } & Mean leaf concentration $\left(\mathrm{mg} \mathrm{g}^{-1}\right)$ & $14.9( \pm 0.1)$ & $1.64( \pm 0.04)$ & $4.9( \pm 0.2)$ & $2.14( \pm 0.04)$ & $8.1( \pm 0.3)$ \\
\hline & Mean litter concentration $\left(\mathrm{mg} \mathrm{g}^{-1}\right)$ & $10.1( \pm 0.5)$ & $0.7( \pm 0.1)$ & $5.2( \pm 0.2)$ & $2.4( \pm 0.2)$ & $2.2( \pm 0.2)$ \\
\hline & Root uptake $\left(\mathrm{kg} \mathrm{ha}^{-1}\right.$ year $\left.^{-1}\right)$ & 32 & 3.0 & 45 & 12 & 21 \\
\hline & Resorption: & & & & & \\
\hline & Absolute $\left(\mathrm{kg} \mathrm{ha}^{-1}\right.$ year-1) & 9.4 & 1.6 & N.d. & N.d. & 5.3 \\
\hline & Relative (\%) & 32 & 49 & N.d. & N.d. & 33 \\
\hline \multirow[t]{2}{*}{ (VR) } & NEI & 98 & 1529 & 196 & N.d. & 445 \\
\hline & GEI & 203 & 2129 & 143 & 539 & 306 \\
\hline \multirow[t]{6}{*}{ Fuenteguinaldo } & Mean leaf concentration $\left(\mathrm{mg} \mathrm{g}^{-1}\right)$ & $12.6( \pm 0.2)$ & $1.58( \pm 0.03)$ & $7.7( \pm 0.3)$ & $1.96( \pm 0.03)$ & $5.4( \pm 0.2)$ \\
\hline & Mean litter concentration ( $\mathrm{mg} \mathrm{g}^{-1}$ ) & $13.1( \pm 0.7)$ & $1.2( \pm 0.1)$ & $8.3( \pm 0.5)$ & $2.2(0.1)$ & $2.6( \pm 0.3)$ \\
\hline & Root uptake $\left(\mathrm{kg} \mathrm{ha}^{-1}\right.$ year $\left.{ }^{-1}\right)$ & 72 & 8.2 & 139 & 13 & 33 \\
\hline & Resorption: & & & & & \\
\hline & Absolute $\left(\mathrm{kg} \mathrm{ha}^{-1}\right.$ year-1) & 11.5 & 1.1 & N.d. & N.d. & 4.7 \\
\hline & Relative (\%) & 27 & 20 & N.d. & N.d. & 26 \\
\hline \multirow[t]{2}{*}{ (FG) } & NEI & 80 & 898 & 124 & N.d. & 344 \\
\hline & GEI & 160 & 1398 & 83 & 889 & 348 \\
\hline
\end{tabular}

Relative resorption related to mineral mass (see text). N.d.: not determined ( \pm standard deviation).

The greatest problem involved in calculating the resorption index for $\mathrm{N}$ is the leaf absorption of $\mathrm{N}$ at the canopy level [29]. Escudero et al. [16] have shown that the maximum $\mathrm{N}$ contents of leaves of $Q$. pyrenaica are reached only 2 bor 3 months after sprouting, the stabilisation phase being prolonged until leaf fall [23]. Since it is not possible to know the exact moment at which leaf $\mathrm{N}$ absorption at the canopy level takes place, it has been assumed that leaf absorption of $\mathrm{N}$ would occur during the initial stages of leaf growth and development owing to the greater demand for $\mathrm{N}$ during this stage (afterwards rainfall decreases [28]).

Accordingly, it is assumed that the amount of leaf absorbed $\mathrm{N}$ would already be included in the mineralmass value (values estimated during the phase when concentrations become stabilised [23]). Thus, to estimate the resorption of $\mathrm{N}(\mathrm{ReN})$, the following expression is used in this case:

$$
\operatorname{ReN}(\%)=\frac{N R-T U}{M M} \times 100
$$

where NR TU, and MM are as above.

\section{Results and discussion}

The results are given in table III.

\subsection{Leaf and leaf-litter composition}

Table III gives the mean nutrient composition of tree leaves and leaf-litter. Granite plots (EP and FG) had 
lower values of $\mathrm{N}$ and $\mathrm{P}$ concentrations in leaves than those found in the schist plots (NF and VR); knowing that leaf and litter production (table $I$ ) are higher in the first two plots than in the latter two stands, these lower $N$ and $P$ concentrations may reflect a dilution effect [19]. The poorest soil (VR) had the highest values of $\mathrm{Mg}$ and $\mathrm{K}$ concentrations and the lowest of $\mathrm{Ca}$, demonstrating a nutrient imbalance [27].

Theoretically, the $\mathrm{Ca}$ and $\mathrm{Mg}$ composition of leaf litter is increased compared to leaf contents because of the loss of organic $\mathrm{C}$ during the decomposition process; but for elements undergoing leaching $(\mathrm{K})$ or resorption $(\mathrm{N}$ and $\mathrm{P}$ ), the nutrient concentration is lower in the leaf-litter than in the tree leaf [27]. Thus, Gallego et al. [23] stated that the chemical composition of the tree leaf changes during the year in these coppices.

\subsection{Tree nutrient uptake (TU)}

Root nutrient uptake is shown in table III.

The sum of return $(L F+T F)$ was previously determined by Gallardo et al. [19] and the annual retention in the trunk and branch biomass by Gallego et al. [23]. Net foliar absorption of $\mathrm{N}$ from atmospheric contributions $[19,29]$ was estimated to be $5.4,6.6,10.2$ and $5.4 \mathrm{~kg}$ $\mathrm{ha}^{-1}$ year $^{-1}$ at NF, EP, VR and FG, respectively; note the high leaf absorption of the stand (VR) with more dystrophic soil.

\subsubsection{Nitrogen}

The total tree $\mathrm{N}$ uptake (root uptake plus leaf absorption) was $51,59,42$ and $78 \mathrm{~kg} \mathrm{ha}^{-1}$ year-1 at NF, EP, VR and FG, respectively. The stands developed on granite (FG and EP) take up more total N (they also have a higher $\mathrm{N}$ root uptake; table $(I I)$ and the highest aboveground production (table I). The supply of $\mathrm{N}$ throughout the mineralisation of abundant soil humus does not seem to be limited [27] except by summer soil dryness [37].

\subsubsection{Phosphorus}

The stands developed on granite (FG and EP) also take up more $\mathrm{P}$ (table III) than those on schist (NF and VR). They require more available soil $P$ to maintain the higher aboveground production (table I). In this case, soil $\mathbf{P}$ is not a limiting factor [37].

\subsubsection{Calcium}

The greater amount of soil $\mathrm{Ca}$ at $\mathrm{FG}$ (table II) leads to a much higher root uptake (139 $\mathrm{kg} \mathrm{ha}^{-1}$ year $\left.^{-1}\right)$ than that observed in the other plots.

\subsubsection{Magnesium}

The plots at VR and FG displayed the most intense $\mathrm{Mg}$ uptake (table III). This higher Mg root uptake in VR is possibly due to $\mathrm{Ca} / \mathrm{Mg}$ nutritional imbalance [27]. In any case, $\mathrm{Mg}$ reserves in soil should contribute to tree nutrition [29].

\subsubsection{Potassium}

FG also has the highest $\mathrm{K}$ root uptake (table III). Owing to the solubility and ease of K leaching [29], a high quantity of $\mathrm{K}$ must be supplied by the soil $\mathrm{K}$ pool.

\subsection{Resorption}

It is assumed that the leaves shed before the normal period of abscission have not undergone resorption of nutrients, according to Carceller et al. [8]; this assumption is difficult to accept if severe defoliation has occurred (e.g. EP). As a result, the inclusion of damaged leaves in the calculation would lead to an underestimation of the resorption index.

\subsection{1. $N$ resorption}

The absolute values of $\mathrm{N}$ resorption (table III) are similar for all the stands, except NF (the stand with the highest rainfall; table I), where the $\mathrm{N}$ resorption is much higher than for other stands. Since the lengths of the abscission periods are very similar because all the plots contain the same species and are subject to almost identical climatic conditions (except rainfall), the calculated values of the resorption index were similar (except for NF with highest precipitation, implying a higher leaf $\mathrm{N}$ leaching and more resorption). There seems to be no relation between resorption indices and soil characteristics.

The relative values of the three drier stands (EP, VR, FG) are lower than those reported by Escudero et al. [16] for $Q$. pyrenaica $(46 \%)$ and for most deciduous species (values between $69 \%$ for Betula pubescens and $37 \%$ for Crataegus monogyna); the value of NF is also lower than those reported by Carceller et al. [8] for Fagus sylvatica $(63 \%)$ and by Chapin and Moilanen [9] for $B$. papyrifera (between 58 and $65 \%$ ). Our results can be considered to be moderate or even low compared with 
those appearing in the literature; this could be a consequence of the different methods used to calculate the indices considered, but the same trend is observed when our results are compared with those of Carceller et al. [8], who used identical calculations. This could indicate that there is not a severe limitation of $\mathrm{N}$ in the coppices studied. The low $\mathrm{N}$ resorption might also be due to leaf absorption of $\mathrm{N}$ by the canopy [29] and it can be assumed that the energy cost for the tree is lower than for high resorption. One can speculate about the idea that the species only display resorption when they are able to derive additional benefits from the use of their strategy and do not become involved in excessive costs (as, for example, when nutrients stored in old leaves can be used more efficiently in other parts of the plant). In view of the low production of fruits [20], this does not seem to occur in the forests studied.

\subsubsection{P resorption}

Concerning the relative values of $\mathrm{P}$ resorption (table $I I I)$, stands on schist (NF and VR) with low available Preserves show values around $50 \%$ and those developed on granitic substrates (FG and $\mathrm{EP}$ ) with higher available P-reserves have values close to $20 \%$. Turrión et al. [37] also observed differences in available $P$ depending on the nature of the parent material. However, within each group, the differences between $P$ resorption values are minimal in spite of the fact that there is four times as much available soil $\mathrm{P}$ at $\mathrm{FG}$ than at EP (table II). The usual clear relationship between available soil $\mathrm{P}$ (in $A h$ horizon) and $\mathrm{P}$ resorption does not exist any more when threshold values of soil availability or plant organs are exceeded; therefore, the nature of the underlying substrate does seem to have some effect on the $\mathrm{P}$ resorption. Furthermore, it is necessary to take the general abundance of micorrhizal fungi into account (Schneider, pers. comm.) in these oak coppices.

The levels of $\mathrm{P}$ resorption vary considerably, being greater overall in deciduous species [35] than in evergreen species. For a single species, in most cases these levels remain almost constant, regardless of the different habitats occupied. The $P$ resorption values recorded are similar to those reported by Sanz [32] for $Q$. pyrenaica (between 33 and $65 \%$ ), for Betula pubescens (76\%) and Fraxinus angustifolia (27\%); by Carceller et al. [8]) for Fagus sylvatica $(50 \%)$; and by Chapin, Moilanen [9] for B. papyrifera (between 27 and $45 \%$ ).

Stands with high $\mathrm{N}$ resorption efficiency also showed greater efficiency in $\mathrm{P}$ resorption (table III). Sanz [32] reported a significant relationship between both indices for different deciduous species and she found the following expression:
$\operatorname{ReP}=5.49+0.98 \times \operatorname{ReN} \quad r=0.70 \quad(P<0.01)$

where $\operatorname{ReP}$ and $\operatorname{ReN}$ are the resorption indices of $\mathrm{P}$ and $\mathrm{N}$, respectively. The slope of the straight line is almost equal to unity, demonstrating the proportionality between both variables.

Obviously, availability of $\mathrm{N}$ and $\mathrm{P}$ are dependent on the mineralisation rate of soil organic matter (and mycorrhizal fungi; Duchaufour [13]); but using the decomposition constants obtained by Martín et al. [27] a non-significant relationship was obtained between these constants and the resorption indices.

\subsubsection{K resorption}

The highest $\mathrm{K}$ resorption is obtained at VR (table III), which is precisely the plot with the lowest soil available $\mathrm{K}$ concentration. However, this factor does not seem to affect the resorption of this element to any considerable extent, because the other plot developed over schist (NF) has a lower content of soil available $\mathrm{K}$ than $\mathrm{EP}$ (table II) and, in contrast, it has the lowest resorption. Therefore, the differences between plots are masked by the participation of two factors (leaf litter return and throughfall) of similar importance.

The relative $\mathrm{K}$ resorption indices (table III) are much lower than the $59 \%$ obtained by Carceller et al. [8] for Fagus sy/vatica forests; it should be stressed that these authors did not consider throughfall, which is very important [29]. It is therefore difficult to establish a comparison between these values.

\subsection{Efficiency indices}

\subsubsection{Nitrogen}

Based on the efficiency indices described, the stands at $\mathrm{EP}, \mathrm{NF}$ and $\mathrm{FG}$ used $\mathrm{N}$ in the least efficient way (table $I I I)$, VR being the most efficient one.

Calculated NEI values (between 71 and 98) were lower than those determined by Ferrés et al. [17] for Quercus ilex (152), Abies sp. (157) and Fagus sylvatica (179), and by Núñez et al. [30] for Cistus laudaniferus (225), but similar to those determined by Carceller et al. [8] for F. sylvatica (99) and those reported by Vitousek [38] for temperate deciduous forests (ranging from 30 to 92).

In the case of N, Birk and Vitousek [4] found that efficiency decreased with the increase in available $\mathrm{N}$. Likewise, Ferrés et al. [17] attributed greater efficiency to reduced $\mathrm{N}$ availability in the soil, caused by delayed decomposition of organic matter due to persistent 
drought in Mediterranean areas. In our work, the soils (EP and NF) with the highest percentage of total $\mathrm{N}$ (table II) appear to make less efficient use of this nutrient. Turrión et al. [37] found that, theoretically, soil $\mathrm{N}$ is not a limiting factor, because of the high amount of total soil $\mathrm{N}$ and the relatively high decomposition rate of soil organic matter [27], but they also pointed out that summer drought can hamper the nitrification and nitrate transport towards the roots [37]. Accordingly, the moderate or even low efficiency values of $\mathrm{N}$ in the forests studied can be said to correspond to moderate or high total soil $\mathrm{N}$ levels, respectively.

It could be expected that the leaf $\mathrm{N}$ resorption does not affect the efficiency of the overall use of this nutrient decisively, because leaf $\mathrm{N}$ leaching and drought also have an influence on $\mathrm{N}$ efficiency.

In summary, there are favourable conditions for the loss of $\mathrm{N}$ in these forests (litterfall coincides with the period of maximum rainfall, as pointed out by Moreno et al. [29], a rapid colonisation of floor litter by microorganisms that slow down the release of $N$ [27] and leaf absorption of this nutrient by the canopy [29]; these factors lead to a low efficiency of this element.

\subsubsection{Phosphorus}

$P$ was used more efficiently in oak coppices located on schist (NF and VR) than in those developed on granites (table III). Turrión et al. [37] found more available P in soils on granite (FG and EP) than in soils on schist. The efficiency indices at VR and NF are very similar; in fact there are no differences in available soil $P$ contents in these two oak coppices (table $I$ ), in contrast to the values found in the other two stands.

FG had the lowest efficiency index, corresponding to a higher content of available $\mathrm{P}$ in the epipedon (table II).

The calculated efficiency indices are lower than those reported by Ferrés et al. [17] for Fagus sylvatica (2 416) but similar to those estimated by the same authors for Abies sp. (1 518) or Quercus ilex (1 246), and similar to the values reported by Carceller et al. [8] for $F$. sylvatica (1 438) and those found by Vitousek [38] for temperate deciduous forests or Mediterranean ecosystems. However, if only the NEI is considered, the FG plot (which has a high content of soil available $\mathrm{P}$; table II) would be less efficient in the utilization of $P$ than the other oak stands and, also, less efficient than a jaral (Cistus laudaniferus) ecosystem of western Spain [30].

\subsubsection{Calcium}

The highest NEI for Ca occurs in the stand with the lowest concentration of soil-exchangeable $\mathrm{Ca}^{2+}$ and a relatively acid soil (VR; table III), while the FG stand has the lowest indices (NEI and GEI) and a higher content of both exchangeable and available $\mathrm{Ca}$ (higher $\mathrm{pH}$ of the epipedon) in the soil.

For this nutrient, GEI seems to be more related to the soil exchangeable $\mathrm{Ca}$ than to available $\mathrm{Ca}$ ( $A h$ horizon).

The efficiency of $\mathrm{Ca}$ for the four oak stands studied here lies within the values given by Vitousek [38] for temperate deciduous forests and is slightly higher than those given by Ferrés et al. [17] for $F$. sylvatica (113) or Q. ilex (111).

Because no deep drainage was observed at FG [28] there is no loss of bases from the soil profile and this explains the much higher $\mathrm{pH}$ and base saturation values of the superficial horizon $(A h)$, compared the other sites (table $I I ;[20,26])$ with the highest aboveground productivity (table I).

\subsubsection{Magnesium}

In the case of this element, only the GEI was estimated since the return of this nutrient to the soil is governed to a large extent by throughfall [29]. Application of this index shows that in the plots studied the order of efficiency for $\mathrm{Mg}$ is directly the opposite to that observed for Ca (table $I I I)$; i.e. VR would be the least efficient plot for $\mathrm{Mg}$ utilization, perhaps because of a possible nutrient imbalance between $\mathrm{Ca}$ and $\mathrm{Mg}$ [26]; i.e. an increase in $\mathrm{Mg}$ uptake in Ca-deficient forest soils. The lowest leaf $\mathrm{Ca} / \mathrm{Mg}$ ratio occurs in VR (2.3) and this ratio is close to 4 in NF and FG. FG showed the highest $\mathrm{Mg}$ efficiency and litter production (table I).

\subsubsection{Potassium}

The plot at NF had the highest GEI for K (table III); there is obviously an inverse relationship between this index and leaf leaching (the quantitative importance of throughfall differs considerably among the stands [19]. The plot at VR has the highest NEI and the lowest K leaching; this index has a limited value in the other plots in this case owing to the intense $\mathrm{K}$ leaching (high solubility of $\mathrm{K}$ ).

\section{Conclusions}

As a result of the present findings, we can conclude that: stands developed on granite annually absorbed greater amounts of $\mathrm{N}, \mathrm{K}$ and $\mathrm{P}$ annually than stands developed on schist, related to their higher aboveground production. 
Bioelement resorption does not affect the NUE of these aak coppices decisively, but is influenced by processes of leaf absorption and leaching occurring in the canopy.

Rainfall differences between sites do not seem to influence the NUE nor the resorption of the stands (except $\mathrm{N}$ resorption in NF). Obviously other factors (besides pluviometry) also influence the NUE, as deduced from the definition of GEI.

In the oak stands studied, the soil nutrient availability governs efficiency in the case of $\mathrm{P}$ and $\mathrm{Ca}$, but not in the case of $\mathrm{N}$ and $\mathrm{K}$. Concerning $\mathrm{N}$ this occurred possibly because the nitrate supply was limited by drought. Leaf absorption and/or leaching at the canopy level would also influence the $\mathrm{N}$ and $\mathrm{K}$ efficiency. Nevertheless, all the oak coppices showed low $\mathrm{N}$ efficiency, indicating that there was no severe $\mathrm{N}$ deficiency.

FG (with the highest litter production and the least dystrophic soil) is the least efficient coppice regarding $\mathrm{Ca}$.

Acknowledgements: The present work was possible thanks to support from the 'Junta de Castilla y León' and finances from the MEDCOP/AIR Project (General Division XII, E. U.) and the Spanish C.I.C.Y.T. Funds. The English version was revised by N. Skinner and the final version by G. Aussenac.

\section{References}

[1] Aerts R., Aboveground biomass and nutrient dynamics of Calluna vulgaris and Molinia caerulea in a dry heathland, Oikos 56 (1989) 31-38.

[2] Aerts R., Nutrient use efficiency in evergreen and deciduous species from heathlands, Oecology 84 (1990) 391-397.

[3] Aerts R., Nutrient resorption from senescing leaves of perennials: are there general patterns?, J. Ecol. 84 (1996) 597-608.

[4] Birk E.M., Vitousek P.M., Nitrogen availability and nitrogen use efficiency in loblolly pine stands, Ecology 67 (1986) 69-79.

[5] Blair G., Nutrient efficiency: what do we really mean?, Dev. Plant Soil Sci. 50 (1993) 205-213.

[6] Bray R.H., Kurtz L.T., Determination of total, organic, and available forms of phosphorus in soils, Soil Sci. 59 (1945) $39-45$.

[7] Bridgham S.D., Pastor J., McClaurgherty C.A., Richardson C.J., Nutrient use efficiency: A litterfall index, a model, and a test along nutrient availability gradient in North Carolina peatlands, Am. Nat. 145 (1995) 1-21.

[8] Carceller F., Roca M.C., Rovira P., Serrano M., Vallejo V.R., Contribución al estudio del ciclo de los nutrientes en los hayedos del Moncayo, in: Silva-Pando F.J., Vega G. (Eds.),
Ponencias y comunicaciones del I Congreso Forestal Español, Junta de Galicia, Pontevedra, 1993, pp. 1:307-312.

[9] Chapin F.S., Moilanen L., Nutritional controls over nitrogen and phosphorus resorption from Alaskan birch leaves, Ecology 72 (1991) 709-715.

[10] Cole D.W., Rapp M., Elemental cycling in forest ecosystems, in: Reichle D.E. (Ed.), Dynamics Properties of Forest Ecosystems, Cambridge University Press, Cambridge, 1981 , pp. 341-409.

[11] Del Arco J.M., Escudero A., Garrido M.V., Effects of site characteristics on nitrogen retranslocation from senescing leaves, Ecology 72 (1991) 701-708

[12] DeLucia E.H., Schlesinger W.H., Photosynthetic rates and nutrient use efficiency among evergreen and deciduous shrubs in Okefenokee swamp, Int. J. Plant Sci. 156 (1995) 19-25.

[13] Duchaufour P., Edafología: Edafogénesis y clasificación, Masson, Barcelona, 1984, 493 pp.

[14] Duvigneaud P., La síntesis ecológica, Alhambra, Madrid, 1978, 306 pp.

[15] F.A.O., Mapa Mundial de suelos: Leyenda revisada, F.A.O., Roma, 1989, 142 pp.

[16] Escudero A., Del Arco J.M., Garrido M.V., The efficiency of nitrogen retranslocation from leaf biomass in Quercus ilex ecosystems, Vegetatio 99-100 (1992) 225-237.

[17] Ferrés L., Rodá F., Verdú A.M.C., Terradas J., Circulación de nutrientes en algunos ecosistemas forestales del Monseny (Barcelona), Mediterranea Ser. Biol. 7 (1984) 139-166.

[18] Gallardo J.F. et al., Final Report about the STEP Project "Nutrient cycling in degenerated natural forests in Europe in relation to their rehabilitation, C.S.I.C., Salamanca, 1992, 100 pp.

[19] Gallardo J.F., Martín A., Moreno G., Santa Regina I., Nutrient cycling in deciduous forest ecosystem of the 'Sierra de Gata' mountains: Nutrient supplies to the soil through both litter and throughfall, Ann Sci. For. 55 (1998) 749-769.

[20] Gallardo J.F., Martín A., Santa Regina I., Nutrient cycling in deciduous forest ecosystems of the 'Sierra de Gata' mountains: Aboveground litter production and potential nutrient return, Ann. Sci. For. 55 (1998) 771-784.

[21] Gallardo J.F., Santa Regina I., Harrison A.F., Howard D.M., Organic matter and nutrient dynamics in three ecosystems of the 'Sierra de Béjar' mountains, Acta Oecol. 16 (1995) $447-459$.

[22] Gallego H.A., Santa Regina I., Rico M., Biomass equations and nutrient distribution for Quercus pyrenaica forests, Mésogée 53 (1993) 75-82.

[23] Gallego H.A., Santa Regina I. Rico M., Rapp M., Variación estacional de la concentración de nutrientes en hojas y ramas en bosques naturales de Quercus pyrenaica Willd. (Sierra de Gata, España), in: Gallardo J.F. (Ed.), Biogeoquímica de ecosistemas, Junta de Castilla y León, Valladolid, 1994, pp. 111-120. 
[24] Krause H.H., Mahendrappa M.K, Comments on 'Nutrient cycling and availability in forest soils', Can. J. Soil Sci. 69 (1989) 187-189.

[25] Mahendrappa M.K., Krause H.H., Foester N.W., Weetman G.F., Krause H.H., Nutrient cycling and availability in forest soils, Can. J. Soil Sci. 66 (1986) 547-572.

[26] Martín A., Gallardo J.F., Santa Regina I., Interaction between litter and soil epipedons in forest ecosystems of the 'Sierra de Gata' mountains, Province of Salamanca, Spain, Arid Soil Res. Rehabil. 9 (1995) 299-305,

[27] Martín A., Gallardo J.F., Santa Regina I., Long term decomposition process of leaf litter from $Q$. pyrenaica forests across a rainfall gradient (Spanish Central System), Ann. Sci. For. 54 (1997) 189-200.

[28] Moreno G., Gallardo J.F., Ingelmo F., Cuadrado S., Hernández J., Soil water budget in four Quercus pyrenaica forests across a rainfall gradient, Arid Soil Res. Rehabil. 10 (1996) 65-84.

[29] Moreno G., Gallardo J.F., Schneider K., Ingelmo F., Water and bioelement fluxes in four Quercus pyrenaica forests along a pluviometric gradient, Ann. Sci. For. 53 (1996) $625-639$.

[30] Núñez E., Martínez J., Escudero J.C., Litterfall and nutrient flux in Cistus laudanifer L. shrubland in S.W. Spain, Acta Oecol. 14 (1993) 361-369.
[31] Pritchett W.L., Properties and management of forest soils, J. Wiley, New York, 1979, 634 pp.

[32] Sanz I., Estudio de la eficiencia en el uso del fósforo en la biomasa foliar de diversas especies leñosas de la Cuenca del Duero, thesis, Facultad de Biologia, Salamanca, 1992, 103 pp.

[33] Schlesinger W.H., DeLucia E.H., Billings W.D., Nutrient use efficiency of woody plants on contrasting soils in the Western Great Basin, Nevada, Ecology 70 (1989) 105-113.

[34] Shaver G.R., Melillo J.M., Nutrient budgets of marsh plants: efficiency concepts and relation to availability, Ecology 65 (1984) 1491-1510.

[35] Son Y., Gower S.T., Aboveground nitrogen and phosphorus use by five plantation-grown tress with different leaf longevities, Biogeochemistry 14 (1991) 167-191.

[36] Staaf H., Plant nutrient changes in beech leaves during senescence as influenced by site characteristics, Acta Oecol., Oecol. Plantarum 3 (1982) 161-170.

[37] Turrión B., Gallardo J.F., González M.I., Nutrient availability in forest soils as measured with anion-exchange membranes, Geomicrobiol. J. 14 (1997) 51-64.

[38] Vitousek P.M., Nutrient cycling and nutrient use efficiency, Am. Nat. 119 (1982) 553-572.

[39] Vitousek P.M., Litterfall, nutrient cycling, and nutrient limitation in tropical forests. Ecology 65 (1984) 285-298. 